Vol. 3 No. 2, 2015

\title{
ANALISIS SEGMENTASI PASAR WISATAWAN MANCANEGARA YANG BERKUNJUNG KE BALI DARI ASPEK SOSIO-EKONOMI DEMOGRAFI, PSIKOGRAFI, DAN PERILAKU
}

\author{
May Sandy Br Ginting \\ I Made Kusuma Negara \\ I Nyoman Sudiarta \\ Email : maysandy@gmail.com \\ PS. S1 Industri Perjalanan Wisata \\ Fakultas Pariwisata UNUD
}

\begin{abstract}
Tourists visiting Bali diverse and consists of various nationalities. In this case the purpose of segmentation is done in order to target the right market to serve customers better and improve the name of Bali as a tourist destination. As for the more specific purpose, among others, to increase sales, improve market share, communication and promotion and strengthening the image. In this case the segmentation analysis is helpful to understand the needs and desires of purchasing power (needs, wants, and purchasing power).

The purpose of this study was to determine differences in behavior, desires and lifestyles of foreign tourists visiting Bali. In conducting the survey questionnaire with a number of researchers spread respondent 138 people were divided on several continents, namely 54 respondents from Europe, 32 respondents from Asia, 30 respondents from Australia and 22 respondents from America. In this study data analysis using SPSS(statistical package for social science) version 20 with Microsoft Excel.

The result showed that differences are significant third against segmentation surveyed: segmentation socio-economic demographic, psychographic, and behavior by continent. Travelers who originated from Europe prefer cultural tourism and stayed $\geq 6$ days, travelers from Australia prefer beach activities and stayed more than 2 weeks, travelers from America also prefer beach activities and stayed $\geq 6$ days, but Asia travelers showed they prefer Adventures activities when they visited Bali and stayed $\geq 6$ days.
\end{abstract}

Keywords : Segmentation, Foreign Tourist, Socio-Economic.

\section{PENDAHULUAN}

Perkembangan kedatangan wisatawan macanegara ke Bali dalam kurun waktu lima tahun terakhir mengalami peningkatan yang cukup pesat, yaitu dari 1.992.299 orang wisatawan macanegara menjadi 2.949.332 orang wisatawan mancanegara pada tahun 2012. Dalam kurun waktu tersebut setiap tahunnya mengalami peningkatan dengan kisaran antara 122.623 orang sampai dengan 392.823 orang per tahun. Dengan peningkatan terbesar terjadi dari tahun 2008 ke tahun 2009 yang mencapai $19,72 \%$. Tahun 2008 krisis ekonomi melanda beberapa negara besar seperti Amerika Serikat dan Juga Jepang. Krisis tersebut berimbas pada hampir seluruh negara di dunia, namun kejadian tersebut tidak berpengaruh secara signifikan terhadap keinginan orang untuk berkunjung ke pulau Bali, terbukti dengan peningkatan jumlah kunjungan wisatawan yang cukup tajam (Badan Pusat Statistik, 2015).

Wisatawan yang berkunjung ke Bali beragam dan terdiri dari berbagai bangsa. Dalam hal ini tujuan dilakukan segmentasi adalah supaya sasaran pasar yang tepat 
untuk melayani konsumen dengan lebih baik dan memperbaiki nama Bali sebagai daerah tujuan wisata. Adapun tujuan lain yang lebih spesifik antara lain yaitu untuk meningkatkan penjualan, memperbaiki pangsa pasar, melakukan komunikasi dan promosi dan memperkuat citra. Disini analisis segmentasi sangat membantu memahami kebutuhan keinginan dan daya beli (needs, wants, and purchasing power) dari wisatawan yang berkunjung ke Bali, maka untuk memberikan kepuasan wisatawan yang berkunjung maka harus wisatawan tersebut dapat dibagi dalam kelompok yang memiliki sifat dan karakteristik yang sama atau faktor kepribadian dan cara hidup sehingga dari berbagai karakteristik dan tujuan wisatawan yang datang ke Bali, semuanya mendapat kepuasan dan sesuai dengan harapan mereka dan pemasaran Bali sebagai destinasi wisata menjadi tepat sasaran. Dalam hal ini penelitian ini dilakukan untuk mengetahui perbedaan segmentasi pasar (socio-ekonomi Demografi, psikografi dan perilaku) wisatawan mancanegara yang berkunjung ke Bali.

\section{TINJAUAN PUSTAKA}

Penelitian yang menjadi acuan peneliti dilakukan oleh Mica Siar Meiriza pada tahun 2005 dengan judul " Analisis Segmentasi Pasar Wisatawan Mancanegara Terhadap Daerah Tujuan Wisata Sumatera Utara" dari Universitas Sumatera Utara yang membahas tentang bagaimana tingkat kepuasan wisatawan mancanegara terhadap akomodasi yang tersedia dan juga meneliti tentang bagaimana pola perjalanan dari tiga daerah asal wisatawan yaitu: ASEAN, Asia Pasifik, dan juga Eropa yang merupakan kunjungan terbanyak asal wisatawan yang datang ke Sumatera Utara. Acuan kedua dalam penelitian ini yaitu dari jurnal internasional "PolyU Study Finds Understanding Market Segments Key to Boosting Reapeat Visits" oleh Ms. Pauline Ngan dari School of Hotel and Tourism Management, The Hongkong Polytechnic University pada tahun 2008 yang membahas tentang alasan utama kunjungan wisatawan tersebut. Hal lainnya yang menjadi fokus penelitian yaitu: jenis kelamin, umur, pendapatan per bulan, pendidikan terakhir yang ditempuh, lama tinggal di Hongkong.

\section{Konsep Tentang Wisatawan}

Definisi wisatawan menurut Norval (Yoeti, 1995) adalah setiap orang yang datang dari suatu tempat/negara yang alasannya bukan untuk menetap atau bekerja di situ secara teratur, dan yang di negara dimana ia tinggal untuk sementara itu membalanjakan uang yang didapatkannya di lain tempat.

\section{Teori Tentang Segmentasi Pasar}

Kotler (2006) mendefinisikan segmentasi juga sebagai:

"Deviding a market to district groups of buyers who might require separate product and/or marketing mix." adalah membagibagi pasar dalam kelompok wisatawan secara tegas dan tiap kelompok itu dipilih atau ditetapkan sebagai target pasar yang akan dipengaruhi dengan menggunakan strategi bauran pemasaran. Dalam kepariwisataan melakukan segmentasi itu merupakan keharusan dan untuk itu dilakukan strategi yang khusus pula dalam melakukan pendekatan kepada masingmasing segmen pasar yang dijadikan sebagai target pasar.

Yoety, (2002) menjelaskan bahwa pengertian segmentasi pasar tidak lain adalah suatu usaha untuk mengelompokkan konsumen dalam beberapa kelompok yang secara relatif orang-orang nya cukup homogen. Segmentasi pasar dibagi menjadi empat kategori besar yaitu: Geografi, sosioekonomi, demografi, psikologi dan prilaku.

1. Segmentasi Geografi yaitu pasar dibagi berdasarkan tempat atau wilayah dapat berupa suatu negara atau kawasan dimana keinginan dan kebutuhannya bervariasi berdasarkan daerah, kota kepadatan penduduk dan iklim.

2. Segmentasi Socio-economi Demografi digunakan sebagai 
variable-variable untuk membagi pasar yaitu: umur, jenis kelamin,

3. Segmentasi Psikografi yaitu pasar dibagi berdasarkan kelompok sosial, karakteristik kepribadian, dan cara hidup. Jadi dalam segmentasi Psikografi yang menjadi acuan adalah konsep pribadi dan cara hidup wisatawan tersebut.

4. Segmentasi Perilaku yaitu variabel yang diambil yaitu wisatawan hampir selalu mencari pengalaman sebanyak mungkin. Pengalaman itu dapat berupa petualangan, hal-hal yang berkaitan dengan sejarah atau bersifat tradisional, gaya hidup yang bersifat sementara. Dasar pemikiran terhadap pendekatan ini adalah keuntungan yang diharapkan oleh wisatawan dan pengalaman yang diperolehnya selama perjalanan wisata yang dilakukan.

\section{Persyaratan Segmentasi yang Efektif}

Menurut Suprapti (2010) untuk memperoleh manfaat yang maksimal dari satu atau beberapa segmen pasar, sebuah segmen pasar harus memenuhi beberapa persyaratan berikut.

a. Dapat diukur (measurable), artinya besar dan daya beli sebuah segmen harus dapat diukur dengan tingkat ukuran tertentu.

b. Dapat dijangkau (accessible), artinya seberapa jauh segmen tersebut dapat dijangkau dan dilayani dengan efektif.

c. Ukurannya cukup besar (substantial), artinya sebuah segmen akan layak bila ukurannya cukup besar atau cukup menguntungkan.

d. Dapat dibedakan (differentiable), artinya segmen yang satu dapat dibedakan dari yang lainnya dan setiap segmen memberi respon yang berbeda terhadap bauran pemasaran.

e. Dapat dilaksanakan (actionable), artinya seberapa jauh program yang efektif dapat ukuran keluarga, pendidikan, ras, penghasilan, agama dan kebangsaan. dirancang untuk menarik dan melayani segmen tersebut.

\section{METODE PENELITIAN}

Penelitian ini dilakukan di Bandara Ngurah Rai Bali tepatnya di terminal keberangkatan internasional, dan teknik pengumpulan data menggunakan kuisioner yang disebar kepada wisatawan mancanegara yang berkunjung ke Bali yang menanyakan tentang profil, gaya hidup, dan perilaku wisatawan yang mencakup empat aspek segmentasi pasar. Jumlah responden adalah sebanyak 138 dengan dan pembagiannya yaitu 54 responden dari Eropa, 32 responden dari Asia, 30 responden dari Australia dan 22 responden dari Amerika.

Jenis dan sumber data yang digunakan yaitu deskriptif kunatitatif dan teknik pengumpulan data dengan cara penyebaran kuisioner dan juga studi kepustakaan.

Dari hasil penelitian yang telah dilakukan maka dari semua asal wisatawan menunjukkan keanekaragaman profil, perilaku dan gaya hidup selama mereka melakukan perjalanan ke Bali. Penggolahaan data penelitian menggunakan program SPSS(statistical package forsocial science) versi 20 dibantu dengan Microsoft Excel untuk memperlihatkan perbedaan profil, perilaku dan gaya hidup tiap-tiap wisatawan.

\section{HASIL DAN PEMBAHASAN}

Segmentasi Pasar

Segmentasi Socio-ekonomi Demografi

Dari hasil penelitian bahwa wisatawan dari Asia adalah wisatawan dengan kunjungan terbanyak ke Bali kedua setelah Australia terutama dari China dan juga mayoritas dari responden tersebut yang berkunjung ke Bali dari Asia yaitu laki-laki denga persentase 53,1\% laki-laki dan 46,9 $\%$ dari responden adalah perempuan. Perbedaan jenis kelamin dari responden tidak terlalu signifikan. Untuk umur wisatawan yang berkunjung 21-30 tahun merupakan responden yang paling banyak 
berkunjung dengan persentase $50 \%$ dan berkebangsaan China dengan persentase $34,4 \%$ yang berumur 31-45 tahun memiliki persentase sebesar 35,2\% atau sebanyak 19 orang responden.

Wisatawan dari Eropa pada umumnya adalah wisatawan yang mandiri dengan perjalanan sendiri. Pendidikan wisatawan yang berasal dari Eropa adalah lulus kuliah dengan persentase $87 \%$ merupakan lulus kuliah. Untuk status pernikahan wisatawan yang berasal dari Eropa adalah 53,7 \% adalah belum menikah dan 42,6\% merupakan wisatawan yang sudah menikah sedangkan 3,7\% atau sebanyak 2 orang dari wisatwan yang berasal dari Eropa sudah bercerai.

Wisatawan Amerika, dari hasil survei yang telah dilakukan juga diperoleh hasil bahwa 40,9 \% dari responden yang berkewarganegaraan Amerika Serikat dan $36,4 \%$ dari mereka adalah berkebangsaan Kanada. Dari keempat benua di dunia Amerika merupakan benua dengan kunjungan terkecil ke Bali. Pendidikan yang ditempuh oleh wisatawan yang berasal dari Amerika dapat juga dilihat bahwa wisatawan dengan pendidikan terakhir 77,3 \% dari mereka lulus kuliah dan untuk wisatawan yang lulus SMA adalah sebesar $22,7 \%$.

Wisatawan Australia adalah wisatawan dengan kunjungan terbanyak ke Bali. Sama halnya dengan wisatawan Amerika, wisatawan yang berasal dari Australia juga sebagian besar dari responden adalah laki laki dengan persentase $63,3 \%$. Pendidikan yang ditempuh dari wisatawan yang berasal dari Australia 76,7 \% dari responden menempuh pendidikan terakhir yaitu lulus kuliah, sedangkan untuk wisatawan yang memiliki pendlidikan terakhir lulus SMA sebesar $23,3 \%$.

Dari hasil penelitian juga dilihat bahwa wisatawan yang berasal dari Australia adalah sebagian besar berumur antara 21-30 tahun yaitu dengan persentase 53,3\%. Untuk status pernikahan wisatwan yang berasal dari Australia adalah 56,7 \% belum menikah dan dengan jumlah keluarga 56,7 $\%$ memiliki jumlah keluarga sebanyak 3-4 orang atau memiliki satu sampai dua anak dalam keluarga.

\subsubsection{Segmentasi Psikografi}

Wisatawan yang berasal dari Asia berkunjung ke Bali dengan Tujuan untuk Liburan dan Bulan Madu. 87,5\% dari wisatawan asal Asia menyatakan bahwa tujuan mereka berkunjung ke Bali adalah untuk liburan dan tujuan bulan madu adalah sebanyak 12,5\%. Untuk Alasan memilh Bali sebagai destinasi wisata yaitu $68,8 \%$ dari responden menyukai wisatwan petualangan selama berlibur di Bali dan $56,3 \%$ menyukai wisata budaya.

Wisatawan asal Eropa berkunjung ke Bali dengan tujuan untuk berlibur dan alasan memilih Bali menjadi tujuan wisata adalah karena Budaya dengan persentase $98,1 \%$ dibandingkan dengan wisata budaya dengan persentase $46,3 \%$. Dari hasil diatas maka diketahui bahwa wisatwan yang berasal dari Eropa lebih menyukai Wisata budaya dibanding dengan wisata petualangan selama berada di Bali.

Wisatawan yang berasal dari Amerika memilih Bali sebagai Destinasi wisata dengan tujuan untuk liburan. Alasan memilih Bali sebagai tujuan wisata adalah karena budaya dan wisata petualangannya dengan persentase 68,2 \% karena budayanya dan $59,1 \%$ karena wisata petualangannya. Untuk wisatawan Amerika, pada umumnya mereka lebih menyukai aktifitas pantai dan cuaca Bali. Wisatawan asal Australia Berkunjung ke Bali dengan tujuan untuk liburan. Dan alasan memilih Bali sebgai destinasi wisata adalah karena budaya Bali sebesar $90 \%$. Wisatawan yang berasal dari Australia juga sangat menyukai budaya Bali saat menghabiskan liburan di Bali. Alasan lainnya memilih Bali juga adalah karena wisata petualangan di Bali. Adapun wisata petualangan tersebut yaitu ada arung jeram, cycling atau bersepeda di Ubud, watersport atau olahraga air di Tanjung Benoa dan yang lainnya

Dari segi status penikahan wisatawan Asia lebih banyak mengunjungi Bali dengan status sudah menikah dengan persentase $53,1 \%$ dari responden tersebut sudah berkeluaga dan $46,9 \%$ adalah belum 
Vol. 3 No. 2, 2015

TABEL 1

\section{SEGMENTASI PASAR WISATAWAN MANCANEGARA YANG BERKUNJUNG KE BALI}

\begin{tabular}{|c|c|c|c|c|c|}
\hline \multirow[t]{2}{*}{ KETERANGAN } & \multicolumn{4}{|c|}{ PERSENTASE (\%) } & \multirow{2}{*}{$\begin{array}{l}\text { JLH } \\
\text { (org) }\end{array}$} \\
\hline & Asia & Eropa & Amerika & Australia & \\
\hline \multicolumn{6}{|c|}{ Tujuan Berkunjung } \\
\hline Berlibur & 87.5 & 100.0 & 100.0 & 100.0 & 134 \\
\hline \multicolumn{6}{|c|}{ Alasan memilih Bali } \\
\hline Budaya & 56.3 & 98.1 & 68.2 & 90.0 & 113 \\
\hline Religi & - & 7.4 & - & - & 4 \\
\hline Petualangan & 68.8 & 46.3 & 59.1 & 66.7 & 80 \\
\hline Fasilitas & 9.4 & 22.2 & 27.3 & 13.3 & 25 \\
\hline Alam & 28.1 & 35.2 & 27.3 & 56.7 & 51 \\
\hline \multicolumn{6}{|c|}{ Faktor pendorong } \\
\hline Cuaca & 34.4 & 63.0 & 86.4 & 86.7 & 90 \\
\hline Harga bersaing & 6.3 & 18.5 & 27.3 & 36.7 & 29 \\
\hline $\begin{array}{l}\text { Destinasi } \\
\text { keluarga }\end{array}$ & 6.3 & 5.6 & 9.1 & 13.3 & 11 \\
\hline Alam natural & 43.8 & 33.3 & 27.3 & 16.7 & 43 \\
\hline $\begin{array}{l}\text { Keramahan } \\
\text { masyarakat }\end{array}$ & 50.0 & 53.7 & 54.5 & 83.3 & 86 \\
\hline $\begin{array}{l}\text { Rekomendasi } \\
\text { seseorang }\end{array}$ & 50.0 & 24.1 & 4.5 & 13.3 & 34 \\
\hline \multicolumn{6}{|c|}{ Aktivitas yang dilakukan } \\
\hline $\begin{array}{l}\text { Mempelajari } \\
\text { budaya }\end{array}$ & 62.5 & 61.1 & 68.2 & 93.3 & 96 \\
\hline $\begin{array}{l}\text { Mempelajari } \\
\text { agama }\end{array}$ & 3.1 & 1.9 & - & - & 2 \\
\hline Aktifitas pantai & 90.6 & 92.6 & 90.9 & 100.0 & 129 \\
\hline \multicolumn{6}{|l|}{ Lama tinggal } \\
\hline 6 hari & 65.6 & 37.0 & 50.0 & 23.3 & 58 \\
\hline $2-4$ minggu & 28.1 & 25.9 & 36.4 & 53.3 & 49 \\
\hline $1-3$ bulan & 3.1 & 35.2 & 4.5 & 10.0 & 23 \\
\hline 3 bulan + & 3.1 & 1.9 & 9.1 & 13.3 & 8 \\
\hline
\end{tabular}

Sumber: Hasil Pengolahan Data Penelitian, 2015

menikah. Jumlah anak dari wisatawan Asia yang berkunjung ke Bali dilihat dari Tabel 4.1 bahwa $56,3 \%$ mengatakan tidak memiliki anak dan untuk wisatawan yang memiliki anak dua atau lebih adalah sebesar $28,1 \%$ atau sebanyak 9 orang responden.

Wisatawan Eropa dari analisa yang telah dilakukan bahwa wisatawan yang berasal dari Eropa 22,2 \% dari responden merupakan kebangsaan Perancis dan 18,5 $\%$ responden berkebangsaan Jerman. Dari segi umur, wisatawan dari Eropa mayoritas merupakan laki-laki dan berumur antara 2130 tahun dengan persentase umur yaitu 40,7 $\%$ sedangkan wisatawan.
Segmentasi Perilaku

Sebagian besar wisatawan dari Asia yang berkunjung ke Bali tinggal selama kurang dari satu minggu. Dan kunjungan wisatawan yang berasal dari Asia tersebut adalah grup. Wisatawan Asia adalah mereka lebih banyak menghabiskan uang dibandingkan dengan wisatawan dari luar Asia dengan perkiraan pengeluran per hari dari wisatawan asal Asia adalah US \$ 100150 untuk pemilihan akomodasi, US \$100150 untuk aktivitas /atraksi di Bali dengan persentase $59,4 \%$ dan US \$ 50-100 untuk makanan dan minuman yang dihabisakan sehari dengan persentase $78,1 \%$.

Wisatawan dari Eropa yang berkunjung ke Bali tinggal selama kurang dari satu minggu. Dan kunjungan wisatawan yang berasal dari Eropa tersebut adalah berpasangan dengan persentase 28,1 $\%$ dan grup dengan persentase $37,5 \%$. Wisatawan asal Eropa berkunjung ke Bali dan juga berkunjung ke daerah-daerah lain seperti Thailand, Vietnam, Malaysia dalam perjalanannya (round trip traveler) Wisatawan yang berasal dari Amerika memilih Bali sebagai Destinasi wisata dengan tujuan untuk liburan. Alasan memilih Bali sebagai tujuan wisata adalah karena budaya dan wisata petualangannya dengan persentase $68,2 \%$ karena budayanya dan $59,1 \%$ karena wisata petualangannya. Untuk wisatawan Amerika, pada umumnya mereka lebih menyukai aktifitas pantai dan cuaca Bali

Wisatawan yang berasal dari Australia berkunjung ke Bali adalah sendiri dengan persentase $43,3 \%$ dan $26,7 \%$ adalah dengan grup. Wisatawan yang sebagian besar dari mereka adalah kunjungan berulang. Lama tinggal wisatawan asal Australia di Bali adalah lebih panjang dibanding dengan wisatwan dari daerah lain seperti Asia, Eropa, dan Amerika. Wisatawan yang berasal dari Eropa lebih menyukai wisata budaya dengan lama tinggal $\geq 6$ hari. 


\section{SIMPULAN DAN SARAN}

Simpulan

Prilaku, gaya hidup dan keinginan wisatawan yang berkunjung ke Bali dari keempat asal negara Asia, Eropa, Amerika dan Australia tersebut memperlihatkan perbedaan yang sangat signifikan. Perbedaan tersebut terlihat pada faktor pendorong melakukan perjalanan, alasan memilih sebuah destinasi, lama tinggal, dan juga dengan siapa wisatawan tersebut memutuskan untuk berlibur.

1. Wisatawan yang berasal dari Eropa lebih menyukai wisata budaya dengan lama tinggal $\geq 6$ hari.

2. Wisatawan yang berasal dari Australia menyukai aktifitas pantai dengan tinggal 2-4 minggu.

3. Wisatawan yang berasal dari Amerika menyukai aktifitas pantai dan kunjungan $\geq 6$ hari selama berlibur di Bali.

4. Wisatawan yang berasal dari Asia menyukai wisata petualangan dengan lama kunjungan di Bali adalah $\geq 6$ hari.

\section{Saran}

1. Disarankan untuk pihak pemerintah maupun pihak swasta dalam memasarkan paket kepada wisatawan untuk lebih jeli terhadap prilaku dan gaya hidup dari masing-masing wisatawan tersebut, dan target pasar tersebut tepat sasaran sesuai dengan keinginan wisatawan.

2. Dinjurkan untuk pihak pemerintah lebih gencar dalam memasarkan pariwisata di kancah internasional, terutama untuk paket-paket wisata yang unik dan baru juga seni budaya Bali yang akan menjadi ciri khas Bali sebagai destinasi wisata.

\section{DAFTAR PUSTAKA}

Badan Pusat Statistik. 2015. Statistik Wisatawan Mancanegara ke Bali Tahun 2015. Denpasar.

Kotler, P. and Armstrong, G. 2006. Principles of Marketing. Eleventh Edition. New Jersey: Prentice Hall International Inc.
Ngan, Ms. Pauline. 2008. PolyU Study Finds Understanding Market Segments Key to Boosting Reapeat Visits. The Hongkong Polythecnic University, Hongkong.

Pendit, Nyoman S. 1999. Ilmu Pariwisata Sebuah Pengantar Perdana. Jakarta: PT. Pradnya Paramita.

Siar Meiriza, Mica. 2005. Analisis Segmentasi Pasar Wisatawan Mancangara Terhadap Daerah Tujuan Wisata Sumatera Utara. Medan: Universitas Sumatera Utara.

Suwena, I Ketut. 2010. Pengetahuan Dasar Ilmu Pariwisata. Denpasar: Udayana University Press

Suprapti, W. 2010. Perilaku Konsumen Pemahaman Dasar dan Aplikasinya Dalam Strategi Pemasaran. Bali: Udayana University Press.

Yoety, Oka A. 1996. Pemasaran Pariwisata Terpadu. Bandung. Angkasa Bandung.

Yoety, Oka A. 2002. Perencanaan Strategis Pemasaran Daerah Tujuan Wisata. Jakarta: Pradnya Paramita. 